\title{
ORIENTASI PENDIDIKAN BERWAWASAN KEBANGSAAN
}

\author{
Oleh :Farid Hasyim*)
}

\begin{abstract}
Restorasi dan reformasi pendidikan bisa menjadi momen penyadaran diri sebagai bangsa akan masalah keadilan dan kesetaraan. Kepekaan terhadap kesenjangan ekonomi dan sosial seharusnya semakin tumbuh dalam kesadaran masyarakat, lebih-lebih dengan adanya suasana yang semakin tidak menentu, dan momen ini akan sia-sia bila pendidikan tidak diarahkan kepada keterbukaan, sifat kritis serta menghormati keanekaragaman struktur politik, ekonomi, sosial dan budaya bangsa yang benar yang sesuai dengan UUD 45 dan falsafah negara dan bangsa Indonesia.
\end{abstract}

\section{Kata Kunci: Orientasi, Pendidikan, Kebangsaan}

\section{A. Pendahuluan}

Dunia pendidikan di Indonesia mengalami perkembangan secara kuantitatif yang sangat menggembirakan, sejak Orde Baru, khususnya mulai Pelita I, perkembangan sektor yang satu ini berkembang dengan pesat. Pemerintah memberikan prioritas yang tinggi pada perkembangan sektor pendidikan didasarkan pada asumsi bahwa dengan pendidikanlah pembangunan ekonomi Indonesia akan berhasil dengan baik. Namun sayang sekali perkembangan itu tidak diikuti dengan peningkatan kualitas yang seimbang. Akibatnya, muncul berbagai ketimpangan pendidikan di tengah-tengah masyarakat, termasuk yang sangat menonjol adalah: a) ketimpangan antara kualitas output pendidikan dan kualifikasi tenaga kerja yang dibutuhkan, b) ketimpangan kualitas pendidikan antara desa dan kota, serta antara penduduk kaya dan penduduk miskin (Karabel,J \& Hasley A.H, dalam Power and Ideology In Education 1977).

Disamping itu muncul dua problem yang terkait dengan persoalan di atas yaitu: pertama, pendidikan cenderung menjadi sarana stratifikasi sosial, dan yang kedua, pendidikan sistim persekolahan hanya mentransfer kepada peserta didik dengan apa yang disebut the dead knowledge, yaitu pengetahuan 
yang terlalu bersifat tex-bookish sehingga bagaikan telah tercabut dari akar sumbernya maupun aplikasinya (Johar dalam Pendidikan Strategik, 2003).

Berbagai upaya pembaharuan pendidikan sesungguhnya telah dilaksanakan dalam rangka meningkatkan kualitas pendidikan, tetapi sejauh ini belum membuahkan hasil, sehingga timbul suatu analisa, bahwa kebijakan pembaharuan pendidikan di tanah air kita sampai saat ini, dapat dikatakan senantiasa gagal bukan semata-mata terletak pada bentuk pembaharuan pendidikan yang bersifat erratic, tambal sulam, melainkan lebih mendasar lagi dikarenakan ketergantungan penentu kebijakan pendidikan kepada pemahaman paradigma peranan pendidikan dalam perubahan sosial yang sudah usang. Ketergantungan ini menyebabkan adanya harapan-harapan yang tidak realistis dan tidak tepat terhadap efikasi pendidikan.

\section{B. Peranan Pendidikan dalam Pembangunan Nasional}

Pembangunan merupakan proses yang berkesinambungan yang mencakup seluruh aspek kehidupan masyarakat, termasuk aspek sosial, ekonomi, politik dan kultural, dengan tujuan utama meningkatkan kesejahteraan warga bangsa secara keseluruhan. Berkaitan dengan peranan pendidikan dalam pembangunan nasional, muncul dua paradigma yang menjadi kiblat bagi pengambil kebijakan dalam pengembangan kebijakan pendidikan, yaitu paradigma fungsional dan paradigma sosialisasi. Paradigma fungsional melihat bahwa keterbelakangan dan kemiskinan itu, lebih disebabkan masyarakat tidak cukup memiliki pengetahuan, kemampuan dan sikap yang modern. Dan paradigma sosialisasi melihat bahwa peranan pendidikan dalam pembangunan adalah: a) mengembangkan potensi individu, b) peningkatan produktivitas, dan c) secara umum, meningkatkan kemampuan warga masyarakat dalam memiliki kemampuan untuk meningkatkan kehidupan masyarakat secara keseluruhan (Zamroni dalam Paradigma Pendidikan Masa Depan,2001).

Berbagai problem pendidikan yang bersumber pada kelemahan pendidikan nasional sistem persekolahan yang tidak mungkin disempurnakan hanya lewat pembaharuan yang bersifat tambal sulam, tetapi hanus dimulai dari mencari penjelasan baru atas paradigma peran pendidikan dalam pembangunan.

Penjelasan paradigma peranan pendidikan dalam pembangunan yang diikuti oleh para penentu kebijakan kita dewasa ini, sebenarnya masih terdapat berbagai kelemahan, baik teoritis maupun metodologis. Pertama, karena belum dapat diketemukan secara tepat dan pasti bagaimana proses pendidikan 
menyumbang pada peningkatan kemampuan individu. Kedua, paradigma fungsional dan sosialisasi memiliki asumsi bahwa pendidikan sebagai penyebab, dan pertumbuhan ekonomi sebagai akibat. Investasi dibidang pendidikan formal sistem persekolahan akan menentukan pembanguan ekonomi dimasa mendatang. Ketiga, paradigma fungisonal dan sosialisasi juga memiliki asumsi bahwa pendapatan individu mencerminkan produktivitas yang bersangkutan. Secara makro upah tenaga kerja erat kaitannya dengan produktivitas, tetapi dalam realitas, asumsiini tidak pernah terbukti. Keempat, paradigma sosialisasi hanya berhasil menjelaskan bahwa pendidikan memiliki peran mengembangkan kompetensi individual, tetapi gagal menjelaskan bagaimana pendidikan dapat meningkatkan produktivitas.

Pembaharuan pendidikan nasional persekolahan seharusnya didasarkan pada paradigma peranan pendidikan dalam pembangunan nasional yang tepat, sesuai dengan realitas masyarakat dan kultur bangsa sendiri. Paradigma peranan pendidikan dalam pembangunan tidak bersifat linier dan unidimensional, sebagaimana dijelaskan oleh paradigma fungisonal dan sosialisasi di atas. Melainkan peranan pendidikan dalam pembangunan sangat kompleks dan bersifat interaksional dengan kekuatan-kekuatan pembangunan yang lain. Dalam konstelasi semacam ini, pendidikan tidak bisa lagi disebut sebagai engine of growth, sebab kemampuan dan keberhasilan lembaga pendidikan formal sangat terkait dan banyak ditentukan oleh kekuatan-kekuatan yang lain, terutama kekuatan ekonomi pada umumnya dan dunia kerja pada khususnya. Hal ini membawa konsekuensi bahwa lembaga pendidikan sendiri tidak bisa meramalkan tentang jumlah dan kualifikasi tenaga kerja yang diperlukan oleh dunia kerja, sebab kebutuhan tenaga kerja baik jumlah dan kualifikasi yang diperlukan berubah dengan cepat sejalan dengan kecepatan perubahan ekonomi dan perubahan dalam masyarakat.

\section{Problem Pendidikan}

Dunia pendidikan di Indonesia masih menghadapi problema yang berat, yang dapat dikategorikan menjadi: a) internal in-efficiency, b) external inefficiency, dan c) ketidak merataan kesempatan pendidikan (lihat Karabel dan Hasley,1977).

Problema Internal in-efisiensi dalam sektor pendidikan berwujud dalam bentuk tingginya angka droup outs dan angka repeaters (ulang- kelas yang sama). Sedangkan eksternal in- efisiensi berwujud lulusan pendidikan tidak dapat diserap oleh pasar tenaga kerja ataupun dapat dipakai, tetapi antara 
pekerjaan yang dilakukan berbeda sama sekali dengan pendidikan yang diperoleh.

ProblemaEksternal in- efisiensi pada sektor pendidikan tidaklah bisa dipisahkan dengan sektor yang lain, khususnya sektor ekonomi dan politik, bahwa modernisasi di bidang ekonomi jauh lebih cepat daripada modernisasi di bidang pendidikan. Perubahan-perubahan pada sistem dan kurikulum pendidikan tidak bisa dilakukan dengan cepat, karena adanya suatu perubahan di sektor pendidikan akan membawa dampak yang sangat luas dan besar pada kehidupan masyarakat secara keseluruhan. Pengalaman pembangunan di negara-negara Barat, sistem dan kurikulum pendidikan dikembangkan dan didasarkan pada keadaan masyarakat saat itu dan proyeksi keadaan masyarakat di masa mendatang. Namun pada era telnologi dewasa ini sangat sulit atau dapat dikatakan hampir tidak mungkin bisa meramalkan tentang keadaan masa mendatang dengan tepat. Akibat dari ketidak-mampuan pendidikan memperhitungkan apa yang akan terjadi di masa mendatang, pendidikan juga tidak mampu untuk menyediakan tenaga kerja yang dibutuhkan oleh sektor ekonomi dan industri, akibatnya adalah naiknya tingkat pengangguran terdidik tidak dapat terelakkan lagi.

Problema ketiga adalah ketidak-merataan kesempatan mendapatkan pendidikan, ini bisa dilihat terutama pada status sosial ekonomi. Teori klasik menyatakan bahwa pendidikan akan selalu menjembatani jurang antara kelompok kaya dan kelompok miskin. Teori Dependency, dengan bukti-bukti empiris dari dunia ketiga, menunjukkan bahwa justru pendidikan memperbesar jurang kelompok kaya dan miskin. Sebab pada pendidikan itu sendiri terdapat stratifikasi sosial (Diana Normida Musnir dalam Sindhunata, Menggagas Paradigma Baru Pendidikan,2000).

Sudah banyak usaha-usaha yang dilaksanakan untuk meningkatkan kualitas pendidikan, termasuk kualitas guru dan pendidikan guru yang dilaksanakan oleh pemerintah. Namun usaha-usaha itu dilaksanakan berdasarkan pandangan dari luar kalangan guru dan atau pendidikan guru,dan terlalu banyak kebijaksanaan di bidang pendidikan yang bersifat teknis yang diambil dengan tanpa menyertakan guru. Pengambilan keputusan yang menyangkut guru seakan-akan melecehkan guru sebagai seseorang yang memiliki kepribadian.

Pengambil kebijakan di bidang pendidikan tidak pernah menghayati apa dan bagaimana yang sesungguhnya terjadi di ruang-ruang kelas. Misalnya, dampak jumlah murid yang besar, keberanian murid untuk menyampaikan gagasan masih sangat rendah, motivasi lebih terarah untuk belajar guna 
menghadapi tes daripada belajar untuk memahami pelajaran yang disampaikan guru, dan sebagainya. Tersendat-sendatnya pelaksanaan CBSA dewasa ini merupakan bukti bahwa setiap kebijakan di bidang pendidikan, apalagi pengajaran di kelas, yang meninggalkan pandangan guru sebagai orang yang paling tahu keadaan kelas cenderung mengalami kegagalan, sebab pandangan guru sangat diperlukan dalam setiap usaha peningkatan kualitas pendidikan.

Begitu juga dalam proses pendidikan, kurikulum harus mendapatkan perhatian yang serius, karena kurikulum menempati posisi yang menentukan. Ibarat tubuh, kurikulum merupakan jantungnya pendidikan, dan ia merupakan seperangkat rancangan nilai, pengetahuan dan keterampilan yang harus ditransfer kepada peserta didik dan bagaimana proses transfer tersebut harus dilaksanakan.

\section{Paradigma Baru Dunia Pendidikan}

Reformasi pendidikan sebenarnya lebih ditujukan untuk meningkatkan komitmen dan kemampuan guru dan murid untuk mencapai prestasi pendidikan sebagaimana yang diharapkan. Dengan reformasi pendidikan dimaksudkan untuk mengembangkan strukkur dan kondisi yang memungkinkan munculnya komitmen dan kemampuan. Oleh karenanya reformasi yang dilakukan harus mencakup tiga aspek dalam pendidikan, yaitu aspek pekerjaan guru dan aspek interaksi sekolah dan masyarakat.

Organisasi sekolah yang berwajah lokal dalam kegiatan nya, cenderung senantiasa mendasarkan pada konsensus lewat dialog dan diskusi yang terbuka dan seimbang.

Trend perkembangan dunia sebagaimana percepatan adanya perubahan sosial, menuntut adanya paradigma baru dunia pendidikan, yaitu adanya pandangan holistis, bahwa pendidikan akan menekankan pada pendekatan yang menyeluruh dan bersifat global. Pandangan ini akan menjadikan dua pembaharuan pada dunia pendidikan, a) pendidikan akan menekankan pada anak didik berpikir secara global dan bertindak bersifat lokal, dan b) pembaharuan bermakna efisiensi, yakni tidak semata-mata bermakna ekonomis, tetapi meliputi pula keharmonisan dengan lingkungan, solidaritas dan kebaikan untuk semua.

Dengan adanya paradigma banu tersebut, maka tuntutan kualifikasi hasil pendidikan otomatis akan mengalami perubahan, bahwa pendidikan akan dituntut untuk menekankan pengembangan kemampuan tertentu pada diri anak didik, 
yaitu: a) kemampuan untuk mendekati masalah secara global dengan pendekatan multidisipliner, b) kemampuan untuk menyeleksi arus informasi yang sedemikian deras, untuk kemudian agar dapat digunakan dalam kehidupan sehari-hari, c) kemampuan untuk menghubungkan peristiwa satu dengan yang lain secara kreatif, d) meningkatkan kemandirian anak, karena tingkat otonomi kehidupan pribadi dan keluarga semakin tinggi, e) menekankan pengajaran lebih pada learning how to learn, daripada learning something. Proses yang berkaitan dengan upaya untuk mengembangkan pada diri seseorang bertumpu pada tiga aspek dalam kehidupannya, yaitu pandangan hidup, sikap hidup dan ketrampilan hidup. Upaya untuk mengembangkan ketiga aspek tersebut bisa dilaksanakan di sekolah, luar sekolah dan keluarga. Kegiatan di sekolah direncanakan dan dilaksanakan secara ketat dengan prinsip-prinsip yang sudah ditetapkan. Pelaksanaan di luar sekolah, meski memiliki rencana dan program yang jelas tetapi pelaksanaannya relatif lebih longgar dengan berbagai pedoman yang relatif fleksibel disesuaikan dengan kebutuhan dan kondisi lokal. Pelaksanaan pendidikan dalam keluarga dilaksanakan secara informal tanpa tujuan yang dirumuskan secara baku dan tertulis.

Dengan mendasarkan pada konsep pendidikan tersebut, maka pendidikan merupakan pembudayaan atau enculturation, suatu proses untuk menjadikan seseorang mampu hidup dalam suatu keadaan dan budaya tertentu. Dan dalam reformasi pendidikan pada dasarnya memiliki tujuan agar pendidikan dapat berjalan lebih efektif dan efisien mencapai tujuan pendidikan nasional. Untuk itu ada dua hal yang perlu dilakukan: a) mengidentifikasi atas berbagai problem yang menghambat terlaksananya pendidikan, dan b) merumuskan reformasi yang bersifat strategik dan praktis sehingga dapat dilakukan di lapangan. Oleh karena itu, kondisi yang diperlukan dan program aksi yang harus diciptakan merupakan titik sentral yang perlu diperhatikan dalam setiap reformasi pendidikan. Dengan kata lain, reformasi pendidikan harus mendasarkan pada realitas sekolah yang ada, dan bukan mendasarkan pada etalase atau jargon-jargon pendidikan semata. Reformasi juga harus melihat dan mendasarkan fakta dan hasil penelitian yang memadai dan valid, sehingga dapat dikembangkan program reformasi yang utuh, jelas dan realistis. Pendekatan sistemik mengisyaratkan agar dalam reformasi tidak ada faktor yang tertinggal dan harus menekankan pada faktor kunci yang akan mempengaruhi faktor-faktor lain secara simultan, sehingga reformasi akan selalu melibatkan seluruh faktor yang penting, dan menempatkan semua faktor tersebut dalam suatu sistem yang bersifat organik. Maka implementasi reformasi pendidikan yang berada di antara kebijakan publik dan kebijakan yang mendasarkan pada mekanisme pasar 
tersebut, memusatkan pada empat dimensi, yaitu dimensi kultural-fondasional, dimensi politik kebijakan, dimensi teknis-operasional, dan dimensi kontekstual.

\section{E. Agenda Reformasi Pendidikan}

Dalam sejarah perkembangan ekonomi di beberapa negara industri, telah banyak membuktikan tesis human investment, pentingnya peran kualitas sumber daya manusia dalam pembangunan, yang kemudian terkenal dengan istilah human reseources based economic development yang merupakan strategi pembangunan, dan strategi ini telah banyak dipraktekkan serta mampu mengantarkan sehingga menjadi negara industri baru, seperti Korea Selatan Singapura, Taiwan dan lain sebagainya.

Pendidikan memegang peranan penting dalam peningkatan kualitas sumber daya manusia, karena dari sistem pendidikan yang berdasarkan filosofis bangsa, akan melahirkan sumber daya manusia yang sesuai dengan kebutuhan pembangunan suatu bangsa. Oleh karena itu perlu dikembangkan dan diperbaharui secara terus menerus upaya untuk melahirkan sistem pendidikan nasional yang barwajah ke-Indonesiaan dan berdasarkan Pancasila.

Pada hakekatnya tujuan utama pendidikan adalah mempersiapkan generasi untuk masa yang akan datang, misalnya pendidikan ditujukan untuk memperhitungkan masa tahun 2005 sampai dengan 2030 berkaitan dengan segala sesuatu yang akan menjadi permasalahan bagi bangsa. Artinya, kita mulai memprediksi hal-hal apa saja yang diinginkan atau harus dihindari, dan hal-hal apa saja yang tidak mungkin dielakkan akan terjadinya. Perhitungan akan berbagai macam kejadian di masa mendatang (the caming era for the caming generation) mesti merupakan suatu studi khusus dan hasilnya mesti dihubungkan dengan kenyataan sekarang sehingga program pendidikan dapat menampung proses pembentukan manusia yang dipersiapkan untuk kemungkinan-kemungkinan tersebut.

Tantangan utama yang dihadapi bangsa Indonesia selama ini memang tertumpu pada kemampuan untuk meningkatkan kualitas sumber daya manusia, dan ini harus dilakukan secara terus menerus sehingga benar-benar menghasilkan sumber daya manusia yang berkualitas sebagaimana yang diharapkan. Dengan demikian bangsa Indonesia akan menjadi bangsa yang produktif, efisien, dan memiliki kepercayaan diri yang kuat serta mampu bersaing dengan bangsa-bangsa lain dalam kehidupan global seperti sekarang terjadi ini. Proses globalisasi ini akan terus merebak, karena itu tidak ada satu wilayahpun yang dapat menghindari dari kecenderungan perubahan yang bersifat global 
tersebut, dan tentu keberuntungan, dan atau problem serta berbagai tantangan sangat mempengaruhinya. Pembangunan pendidikan juga harus senantiasa bisa menganitisipasi kecenderungan-kecenderungan global yang akan terjadi.

Beberapa kecenderungan global yang perlu untuk diantisipasi oleh dunia pendidikan antara lain adalah, Pertama proses investasi dan re-investasi yang terjadi di dunia industri berlangsung sangat cepat, menyebabkan terjadinya perubahan-perubahan yang sangat cepat pula pada organisasi kerja, struktur pekerjaan, struktur jabatan, dan kualifikasi tenaga kerja yang dibutuhkan. Sebaliknya, praktek pendidikan tradisional berubah sangat lambat, akibatnya mismatch education and employment cenderung semakin membesar. Kedua, perkembangan industri, komunikasi dan informasi yang semakin cepat akan melahirkan "knowledge worker" yang berkaitan erat dengan information processing yang semakin besar jumlahnya. Ketiga munculnya kecenderungan bahwa pendidikan telah bergeser dari ide back to basic ke arah ide the forward to future basics, yang mengandalkan pada kemampuan TLC (how to think, how to learn and how to create). How to think menekankan pada pengembangan critical thinking, how to learn menekankan pada kemampuan untuk bias secara terus menerus dan mandiri menguasai dan mengolah informasi, dan how to create menekankan pada pengembangan kemampuan untuk dapat memecahkan berbagai problem yang berbeda-beda. Keempat, berkembang dan meluasnya ide demolratisasi yang bersifat substansi, yang antara lain dalam dunia pendidikan akan terwujud dalam munculnya tuntutan pelaksanaan school based management dan site-specific solution.

Seiring dengan itu, karena kreatifitas guru, maka akan bermunculan berbagai bentuk praktek pendidikan yang berbeda-beda satu dengan yang lain, yang kesemuanya untuk menuju pendidikan yang produktif, efisien, relevan dan berkualitas.

Sudah banyak usaha-usaha yang dilaksanakan untuk meningkatkan kualitas pendidikan, termasuk kualitas guru dan pendidikan guru yang dilaksanakan oleh pemerintah. Namun usaha-usaha itu dilaksanakan berdasarkan pandangan dari luar kalangan guru dan atau pendidikan guru,dan terlalu banyak kebijaksanaan di bidang pendidikan yang bersifat teknis yang diambil dengan tanpa menyertakan guru. Pengambilan keputusan yang menyangkut guru seakan-akan melecehkan guru sebagai seseorang yang memiliki kepribadian.

Pengambil kebijakan di bidang pendidikan tidak pernah menghayati apa dan bagaimana yang sesungguhnya terjadi di ruang-ruang kelas. Misalnya, 
dampak jumlah murid yang besar, keberanian murid untuk menyampaikan gagasan rendah, motivasi lebih terarah untuk belajar guna menghadapi tes daripada belajar untuk memahami pelajaran yang disampaiakan guru, dan sebagainya. Tersendat-sendatnya pelaksanaan CBSA dewasa ini merupakan bukti bahwa setiap kebijakan di bidang pendidikan, apalagi pengajaran di kelas, yang meninggalkan pandangan guru sebagai orang yang paling tahu keadaan kelas cenderung mengal;ami kegagalan, sebab pandangan guru sangat diperlukan dalam setiap usaha peningkatan kualitas pendidikan.

Begitu juga dalam proses pendidikan, kurikulum harus mendapatkan perhatian yang serius, karena kurikulum menempati posisi yang menentukan. Ibarat tubuh, kurikulum merupakan jantungnya pendidikan, dan ia merupakan seperangkat rancangan nilai, pengetahuan dan keterampilan yang harus ditransfer kepada peserta didik dan bagaimana proses transfer tersebut harus dilaksanakan.

\section{F. Penutup}

Untuk menemukan pendidikan yang berakar pada budaya bangsa, perlu dilaksanakan penajaman penelitian pendidikan, tetapi tidak harus bersifat eksklusif, karena hal ini bias bertentangan dengan realitas globalisasi. Oleh karenanya harus memahami globalisasi yang dapat dikaji dari prespektif kurikuler dan prespektif reformasi. Tantangan yang mendasar adalah bagaimana melakukan reformasi pendidikan yang pada akhirnya dapat mempengaruhi level kelas. Sejalan dengan upaya menemukan pendidikan yang berwajah Indonesia yang bermutu, kemampuan guru, kemauan guru dan kesejahteraan guru mutlak harus ditingkatkan. Guru di masa mendatang akan menghadapi persoalan-persoalan yang berbeda pada masa kini, kurikulum bagaikan paruparu pendidikan. Oleh karena itu guru harus bisa mengimplementasikan kurikulum dalam level kelas. Permasalahan ketimpangan dalam ruang kelas yang berujud prestasi siswa, tidak bisa dilepaskan dari ketimpangan sosial ekonomi keluarga. Secara kongkrit pada level kelas harus dikembangkan kebijakan untuk mengurangi ketimpangan tersebut. Cooperative Learnig Model diharapkan akan dapat mempersempit ketimpangan prestasi siswa. Prestasi siswa memang tidak hanya ditentukan oleh kemampuan mengajar guru semata, tetapi kultur sekolah juga ikut menentukan dan memegang peran penting. Dan sudah barang tentu pembentukan serta peran kepala sekolah sangat penting, karena itu kualitas pendidikan tidak hanya dapat diartikan pencapaian prestasi akademik semata, perlu juga dibahas tentang prestasi atau hasil pendidikan secara utuh. 


\section{DAFTAR PUSTAKA}

Davis, I.K., The Management Learning, London: Mc Graw-Hill Book Co, 1971

Degeng, I.N.S., Ilmu Pengajaran Taksonomi Variabel, Jakarta: Depdikbud Dirjen Dikti, 1989

Johar, Pendidikan Strategik Untuk Pendidikan Masa Depan, Yogyakarta: LESFI, 2003

Karabel, J\& Hasley, A.H., Power and Ideology In Education, New York: Oxford University Press, 1997

Mochtar Buchori, Pendidikan dalam Pembangunan, Yogyakarta: Tiara Wacana, 1994

Noeng Muhadjir, Ilmu Pendidikan dan Perubahan Sosial, Yogyakarta: Rake Sarasin, 1987

Piet A. Sahertian, Profil Pendidik Profesional, Yogyakarta: Andi offset,1994

Sindhunata, Menggagas Paradigma Baru Pendidikan, Demokratisasi, Otonomi, Civil Cociety, Globalisasi, Yogyakarta: Kanisius, 2000

Singgih Gunarsa, Ny. Singgih Gunarsa, Psikologi Perkembangan Anak dan Remaja, Jakarta: BPK Gunung Mulia,1989

Soerjanto Poespowardojo, Re-orientasi Ilmu Pendidikan di Indonesia, Jakarta: Educatio, IKIP Muhammadiyah Jakarta Press, 1996

Soerjanto Poespowardojo dan Frans M Perera, Pendidikan Wawasan Kebangsaan, Jakarta: Grasindo, 1994

Zamroni, Paradigma Pendidikan Masa Depan, Yogyakarta: Bayu Indra Grafika, 2001

*) Penulis adalah Dosen Tetap Fak. Tarbiyah UIN Malang, peserta Program Doktor IAIN Sunan Ampel Surabaya 